\title{
High Temperature Gas-Cooled Reactor Criticality Research Program
}

\author{
by \\ S. R. Bierman \\ E. D. Clayton
}

June 1976

Prepared for the Energy Research and Development Administration under Contract E(45-1)-1830 


\section{NOTICE}

This report was prepared as an account of work sponsored by the United States Government. Neither the United States nor the Energy Research and Development Administration, nor any of their employees, nor any of their contractors, subcontractors, or their employees, makes any warranty, express or implied, or assumes any legal liability or responsibility for the accuracy, completeness or usefulness of any imformation, apparatus, product or process disclosed, or represents that its use would not infringe privately owned rights.

PACIFIC NORTHWEST LABORATORY

operated by

BATTELLE

for the

ENERGY RESEARCH AND DEVELOPMENT ADMINISTRATION

Under Contract E(45-1)-1830

Printed in the United States of America

Available from

National Technical Information Service

U.S. Department of Commerce

5285 Port Royal Road

Springtield, Virginia 22151

Price: Printed Copy S4.50; Microfiche $\$ 2.25$ 
33679000626681

\section{HIGH TEMPERATURE GAS-COOLED REACTOR \\ CRITICALITY RESEARCH PROGRAM}

by

S. R. Bierman

E. D. Clayton

June 1976

Report sponsored by the Thorium Utilization Program Office, Oak Ridge National Laboratory, and prepared for the U. S. Energy Research and Development Administration Under Contract AT $(45-1): 1830$.

BATTELLE

PACIFIC NORTHWEST LABORATORIES

RICHLAND, WASHINGTON 


\section{CONTENTS}

EXECUTIVE SUMMARY $\ldots \ldots \ldots \ldots \ldots \ldots \ldots \ldots \ldots \ldots \ldots \ldots \ldots \ldots \ldots \ldots \ldots \ldots \ldots \ldots$

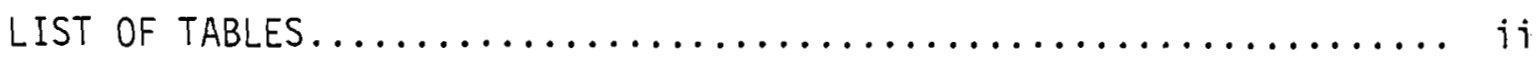

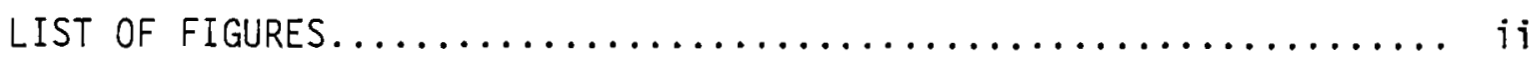

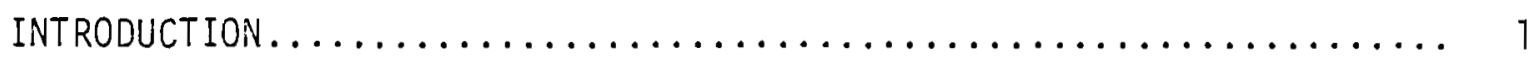

GENERAL DESCRIPTION OF CRITICALITY EXPERIMENTS

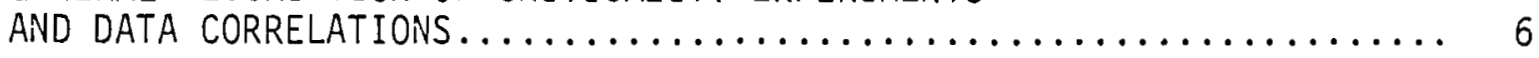

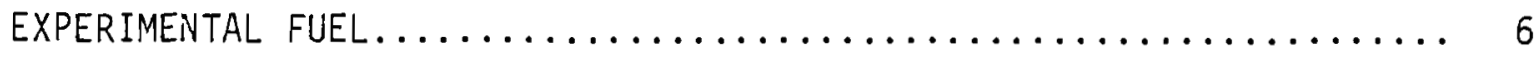

CRITICALITY RESEARCH PROGRAM.......................... 8

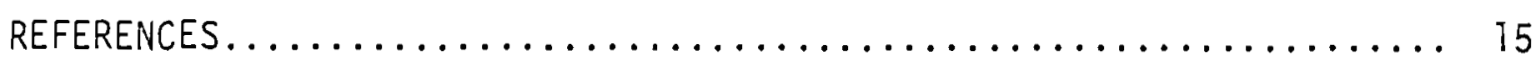

APPENDIX - HTGR FUEL CYCLE PROCESS STEPS AND MATERIAL

FORMS PERTINENT TO CRITICALITY PREVENTION.................... 16 


\section{EXECUTIVE SUMMARY}

The objective of this report is to define the nuclear criticality research program needed in support of the High Temperature Gas-Cooled Reactor (HTGR) fuel cycle outside reactors. To meet this objective, an experimental plan, and the supportive calculational efforts, are presented herein, which, over a seven-year period, will provide sufficient information to permit maximizing plant equipment and operations.

To minimize the restrictions placed on HTGR plant equipment and operations by criticality considerations, experimental criticality data are needed over a sufficient range of operating variables to permit either direct appiication to plant conditions or verification of calculational techniques used in establishing safe limits. Currently, some data on we17-moderated ${ }^{235} \mathrm{U}$ and ${ }^{233} \mathrm{U}$ exist which are appiicable to the thorium-uranium fuel mixtures expected to be encountered in nonreactor facilities handling HTGR fuels. However, experimental data are needed for undermoderated ${ }^{235} U$ and ${ }^{233} U$ systems. Data are needed also on ${ }^{235} U$ and $233 U$ containing soluble neutron poisons and in the presence of fixed neutron poisons. Also, few, if any, useful experimental data exist for thorium-uranium mixtures. However, this lack of data on Th-U mixtures is not of immediate concern, since currently envisioned processes are such that criticality limits must be established on the basis of uranium alone. For future fuels and processes in which the nonfissile diluent thorium and the fissile uranium cannot be separated, there would be a large economic incentive for including the thorium in the criticality considerations.

The research program presented herein covers all aspects of the experiments needed to provide data in the above areas. This includes the form, procurement, and processing of the experimental fuel in addition to the funding levels currently estimated for accomplishing the various phases of the program. 


\section{LIST OF TABLES}

Table I - Sumary of Available Criticality Data Applicable to the HTGR Fuel Cycle............... 4

Table II - Fuel Preparation Schedule and Current Estimate of Cost Involved - HTGR Criticality Experiments........ 9

Table III - Projected Funding Schedule................. 14

\section{LIST OF FIGURES}

Figure 1 - HTGR Fuel Fabrication Pilot Plant - ORNL............ 2

Figure 2 - HTGR Fuel Reprocessing Demonstration Plant at Idaho Falls............................... 3 
HIGH TEMPERATURE GAS-COOLED REACTOR

CRIT ICALITY RESEARCH PROGRAM

S. R. Bierman and E. D. Clayton

INTRODUCTION

The objective of the High Temperature Gas-Cooled Reactor (HTGR) Fuel Recycle Development Program is to develop recycle technology such that commercial plants for reprocessing and refabrication of HTGR fuels can be built and operated economically. (1) However, it is also necessary that these plants be operated such that nuclear criticality accidents do not occur. To assure criticality safety in such operations, limits are required on the equipment design and on the amount of fuel that may be handled or processed at any one location at any one time. These limits or controls present the main restrictions to plant throughput and, thus, the overall plant economy. The criticality control limits may dictate operations which are far from optimum, technically and economically, and the greater the uncertainty in a knowledge of criticality for a given operation, the more severe the restrictions become.

Flow diagrams for the HTGR Fuel Fabrication Pilot Plant (ORNL) and the HTGR Fuel Reprocessing Demonstration Plant (Idaho Falls) are shown in Figures 1 and 2, respectively. The complexity of criticality prevention in these operations becomes apparent when considering the fuel forms encountered. These forms and the anticipated conditions to be encountered are presented in the Appendix.

To minimize the restrictions placed on HTGR plant equipment and operations by criticality considerations, experimental criticality data are needed over a sufficient range of operating variables to permit either direct application to plant conditions or verification of calculational techniques used in establishing safe plant limits. The criticality data currently available on thorium-uranium fuel mixtures are listed in Table I, as well as in the Appendix. of this currently available data, essentially only the well-moderated data for $235 U$ and $233 U$ are appicable to the thorium-uranium fuel mixtures expected to be encountered in nonreactor facilities handiing HTGR fuels. Experimental data are needed for undermoderated ${ }^{235} U$ and ${ }^{233} U$ systems. Data are needed also on ${ }^{235} U$ and ${ }^{233} U$ containing soluble neutron poisons and in the presence of fixed neutron poisons. Also, few, if any, useful experimental data exist for thorium-uranium mixtures. However, this lack of data 
HTGR FUEL FABRICATION PILOT PLANT-ORNL

(BASIC FLOW DIAGRAM)
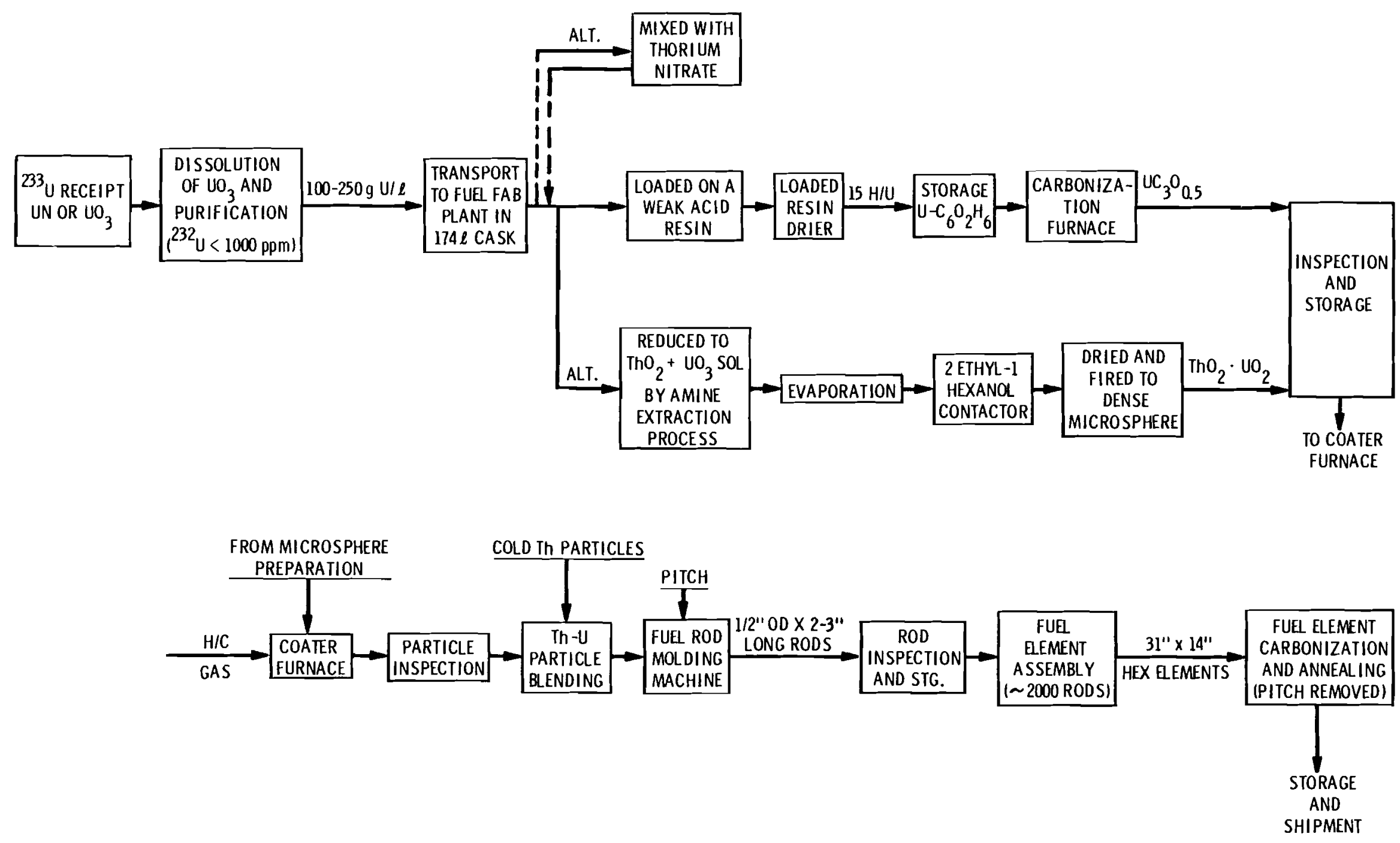

FIGURE 1 


\section{HTGR FUEL REPROCESSING DEMONSTRATION PLANT AT IDAHO FALLS}

\section{(BASIC FLOW DIAGAAM)}
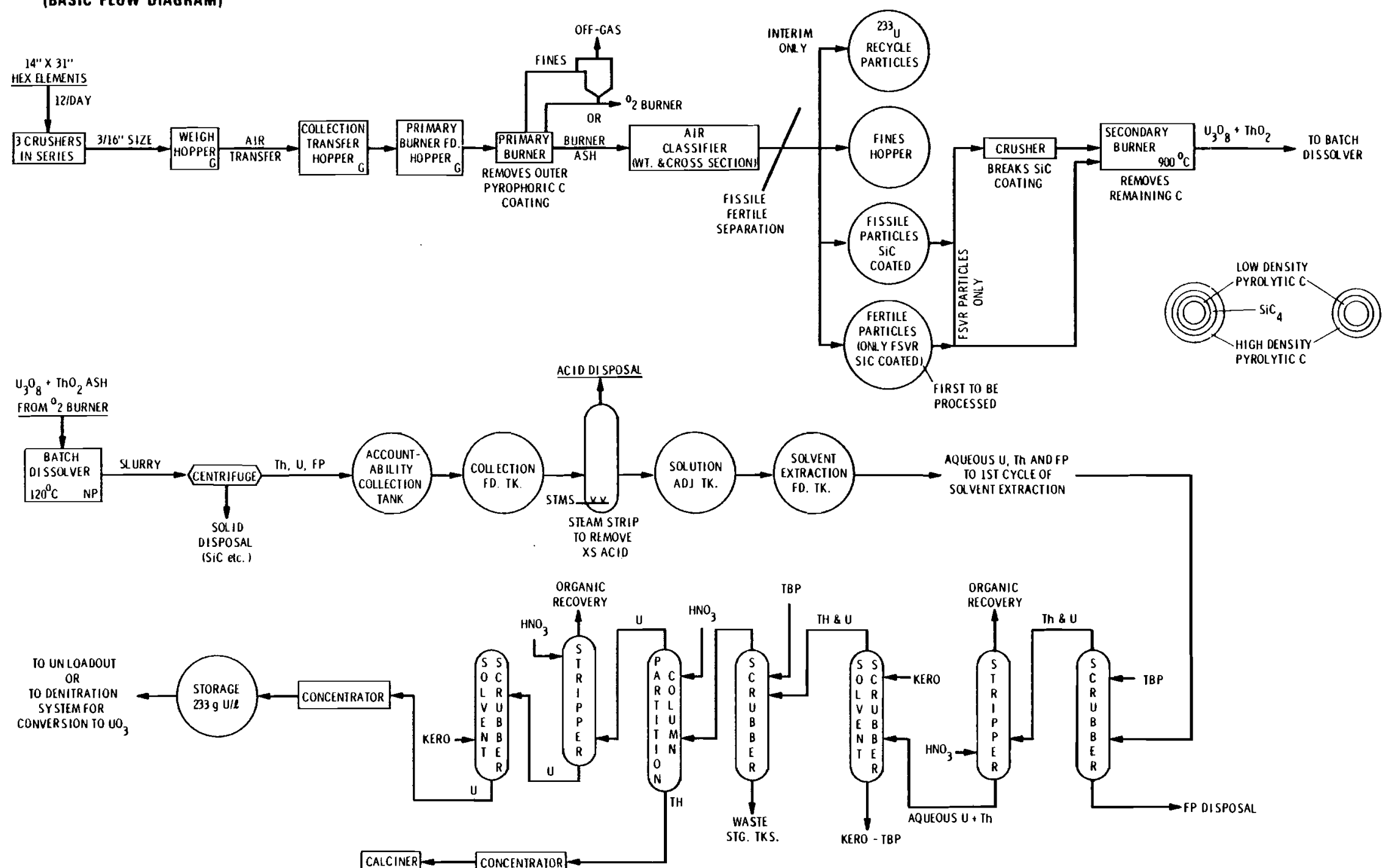


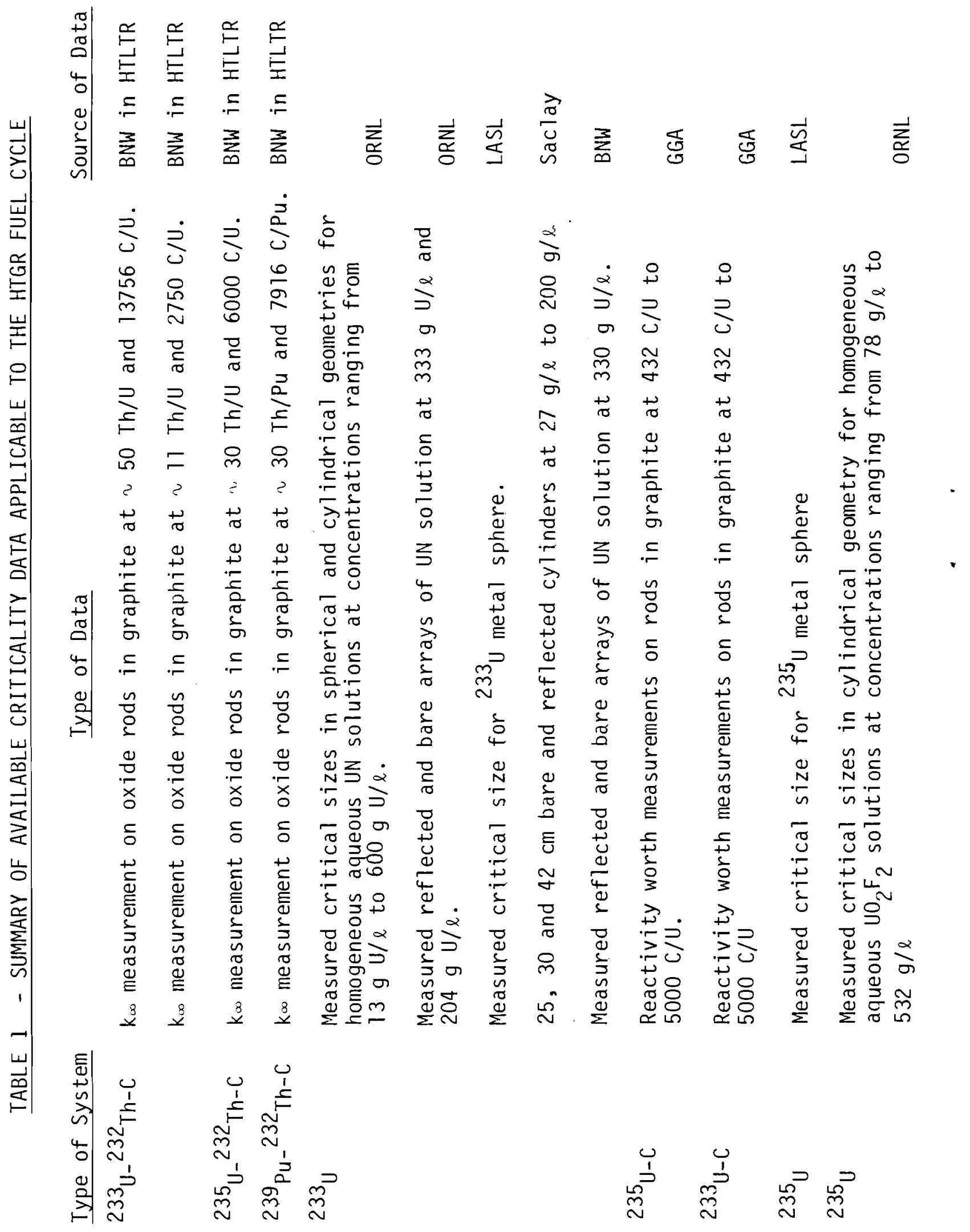


on Th-U mixtures is not of immediate concern, since currently envisioned processes are such that criticality limits must be established on the basis of uranium alone. For future fuels and processes in which the nonfissile diluent thorium and the fissile uranium cannot be separated, there would be a large economic incentive for including the thorium in the criticality considerations.

The primary area in which criticality data are needed is that of undermoderated ${ }^{235} \mathrm{U}$ and ${ }^{233} \mathrm{U}$. In the fuel fabrication plant, uranium loaded resins having $\mathrm{H} / \mathrm{U}$ atomic ratios ranging from about 7 to 60 are possible between the loading of the weak acid resin, as feed stock to the carbonization furnaces, and the coater furnaces. Experimental criticality data exist for metal spheres of $235_{U}(2)$ and $233_{U}(3)$ but none are available for either of these nuclides in the presence of a small amount of moderation. Experimental data on low-moderated, about $20 \mathrm{H} / \mathrm{U}$, uranium are also needed to support the design and operation of head-end equipment in the chemical reprocessing plant. The situation of most concern occurs when a small fraction of dissolver solution is slurried with fissile particles. Overly restrictive limits on the primary and secondary burners can also be crucial to the reprocessing plant's throughput capacity.

Since soluble neutron absorbers, such as cadmium, boron, and gadolinium, will almost certainly be required, as neutron poisons, to achieve an adequate fuel dissolution capacity in the reprocessing plant, criticality data are also needed for these low-moderated systems containing representative amounts of these neutron absorbing materials. Because of dilution during and following fuel dissolution, criticality data on these neutron poisons are also required for the more moderated systems up to $\mathrm{H} / \mathrm{U}$ atomic ratios of about 200 .

Plant throughput capacity and storage capacity can also be enhanced by the use of fixed neutron absorbers such as borated stainless steel raschig rings. 
Data on these types of systems are lacking and needed over the H/U atomic ratio range of 50 to 300 .

GENERAL DESCRIPTION OF CRITICALITY EXPERIMENTS AND DATA CORRELATIONS

Criticality measurements would be made on highly enriched homogeneous uranium systems to determine the effect of uranium concentration on the critical mass and volume. A concentration range from about $85 \mathrm{~g}$ U/liter $(300 \mathrm{H} / \mathrm{U})$ to about $1100 \mathrm{~g} \mathrm{U} / 1 \mathrm{iter}(12 \mathrm{H} / \mathrm{U})$ will be covered in the experiments to provide the needed data on undermoderated systems ( $\sim 10$ to $50 \mathrm{H} / \mathrm{U}$ ) and the data needed for systems containing soluble and fixed neutron poisons. Critical masses and volumes will be determined over a concentration range from $85 \mathrm{~g} \mathrm{U} / 1$ iter to $450 \mathrm{~g}$ U/liter in a cylindrical vessel filled with 4 wt\% borated stainless steel raschig rings. Criticality data will be obtained over the fulT 85 to $1100 \mathrm{~g} \mathrm{U} / 1$ iter concentration range with soluble boron, cadmium, and gadolinium compounds to measure the poisoning effects these nuclides have on the criticality of $235 \mathrm{U}$ and ${ }^{233} \mathrm{U}$. Measurement data will be obtained also on mixtures of these soluble poisons, since calculations have indicated that these nuclides are more effective neutron absorbers at different portions of the neutron spectrum. (4)

The experiments would be carried out in wel1-defined cylindrical geometry to permit a maximum amount of direct correlation to be made between the needed data, and to minimize the number of fuel composition adjustments required during the course of the experiments. As near as possible, identical sets of measurement data wi11 be obtained for ${ }^{235} U$ and ${ }^{233} U$. EXPERIMENTAL FUEL

Several fuel forms were considered for use in the experiments. These were: 
1. Uranyl fluoride solution

2. Uranyl nitrate solution

3. Uranium oxide-polystyrene compacts

4. Loaded resin microspheres

5. Coated microspheres in hydrogenous compacts

Fuel in the form of compacts was eliminated from consideration because of its high fabrication cost and the restrictive time interval imposed by radiation exposures associated with ${ }^{233} U$ fuel. Also, wherever possible, fuel in solution form is preferred for the homogeniety not achievable in any other fuel form.

Loaded resin microspheres were eliminated from consideration as an experimental fuel because of the difficulty associated with particle flow, achievement of uniform bulk densities, wide $H / X$ ranges required, and uniform addition of neutron absorbers.

of the two solution forms, uranyl nitrate was considered to be the best choice. Uranyl nitrate hexahydrate, UNH, has an H/U atomic ratio of 12 and is in the liquid state at $60^{\circ} \mathrm{C}$. Saturated aqueous uranyl fluoride at $60^{\circ} \mathrm{C}$ has an $H / U$ atomic ratio of only 17 , in addition to some viscosity problems and corrosion problems as saturation is approached. Also, UNH can be easily diluted, with relatively-easy-to handle nitric acid or with water, to achieve the $H / U$ ratios required. Consequently, UNH was chosen as the fuel form to be used throughout the experiments.

Because of the difficulties currently associated with cross-country shipment of 1 iquid radioactive material, Oak Ridge National Laboratory (ORNL) will provide the uranium fuel in the form of a uranium salt or as $\mathrm{UO}_{2}$ enriched to at least $93 \mathrm{wt} \%$ in ${ }^{235} \mathrm{U}$ and ${ }^{233} \mathrm{U}$. The fuel, after shipment to the Battelle 
Pacific Northwest Laboratory (BPNL), will be dissolved and reconcentrated to dry UNH by BPNL to achieve a $12 \mathrm{H} / \mathrm{U}$ atomic ratio. The UNH wil1 be received as a solid at the Critical Mass Laboratory (CML), reliquified, by heating to approximately $60^{\circ} \mathrm{C}$, and transferred to geometrically safe storage tanks maintained at $60^{\circ} \mathrm{C}$ to $65^{\circ} \mathrm{C}$. H/U variations will be obtained by dilution with nitric acid and water.

The anticipated cost and timing associated with fuel preparation and handling is itemized in Table II.

\section{CRITICALITY RESEARCH PROGRAM}

The research program is directed towards providing the reliable technological basis needed for assuring safe and economical criticality control throughout the HTGR fuel cycle, including the design and operation of equipment and facilities in fabrication, shipping, and processing operations. All the activities required to meet these objectives are covered in this program. Both experimental and analytical work are involved. Specifically, the program includes:

1) Identification and procurement of the data required for criticality safety in HTGR fuel cycle operations.

2) Data testing and analysis to provide validated analytical methods with ENDF/B cross sections (to guide selection and implementation of improved analytical methods).

3) Development of standards or guides on criticality prevention and control for fuel cycle operations covering limits for fuel fabrication and reprocessing.

4) Performance of survey calculations and development of general criticality data which serve as a basis for evaluating the criticality safety aspects of advanced processes in fuel cycle. 
TABLE II

FUEL PREPARATIOII SCHEDULE AND CURRE:IT ESTIMATE OF COSTS INVOLVED HTGR CRITICALITY EXPERIMENTS (1)

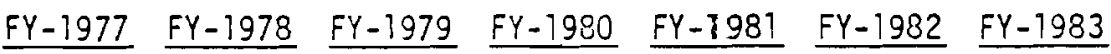

1. Preparation of $50 \mathrm{~kg}$ Naturai UNH by BPNL

BPNL

2. Preparation of $50 \mathrm{~kg} 93 \mathrm{wt} \%$

$--\quad \$ 50 k \quad---\quad \$ 60 k$

3. Shipment of $50 \mathrm{~kg} 93 \mathrm{wt} \%$

$235 \mathrm{U}$ Enriched $\mathrm{UO}_{2}$ From ORNL to BPNL

$---\quad B P N L$

4. Dissolution of $50 \mathrm{~kg} 93 \mathrm{wt}_{\%}^{\prime \prime}$

$235 \mathrm{U}$ Enriched $\mathrm{UO}_{2}$ and Concentration to UNH

$\begin{array}{llll}-- & \text { BPNL } & -- & \text { BPNL }\end{array}$

5. Concentrate Aqueous $235 \mathrm{U}(93) \mathrm{NH}$ to UNH

6. Removal of Cd from Aqueous 235 INH Solution and Concentration to $235 \mathrm{UNH}$

7. Concentrate Aqueous ${ }^{235}$ UNH Solution Containing Gd

8. Remove $G d$ and $B$ from Aqueous $235 \mathrm{U}(93) \mathrm{NH}$ Solution and Return to ORNL

9. Preparation of $50 \mathrm{~kg} 93 \mathrm{wt}: \%$ 233 U Enriched $\mathrm{UO}_{2}$ by ORNL

10. Shipment of $50 \mathrm{~kg} 93 \mathrm{wt} \%$ $233 \mathrm{U}$ Enriched $\mathrm{UO}_{2}$ from ORill to BPilL

11. Rissolution of $50 \mathrm{~kg} 93 \mathrm{wt} \%$ $233 \mathrm{y}$ Enriched $\mathrm{UO}_{2}$ and concentration to UNH

12. Purify and Concentrate Aqueous $233 \mathrm{U}(93) \mathrm{NH}$ Solution to UNH
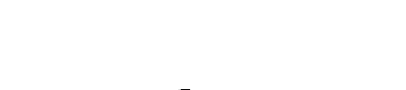

BPNL
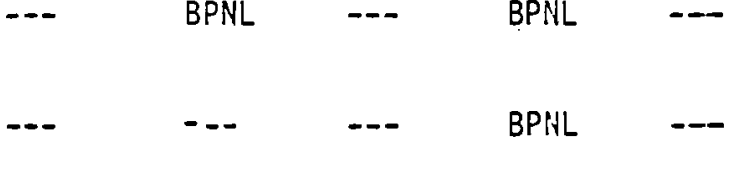

BPNL
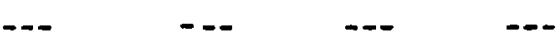

BPtiL
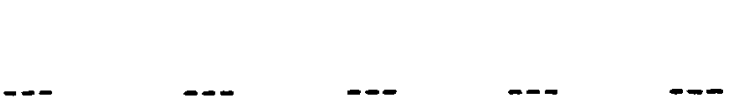

BPNL 
To accomplish these objectives in a timely and logistically feasible manner the various program activities have been categorized on a fiscal year basis beginning with fiscal year 1977 . Each year's activities are based on an anticipated funding level, projected work load at the Critical Mass Laboratory, and the scheduling involved with fuel adjustment, purification, and storage. Some flexibility is possible in the time schedule; however, there is very little room for compression.

The anticipated funding level does not include cost associated with the preparation and handling of the experimental fuel. These costs are delineated in the preceding section on Experimental Fuel. A total projected funding schedule is broken down and shown in Table III.

FY-1977 ANTICIPATED FUNDING LEVEL: $\$ 85 \mathrm{k}$

Pre-experiment planning and design will be continued, including procurement . arrangements for the various fissile materials required to perform the experiments. Storage vessels and experimental equipment will be procured and installed. Natural uranium as UNH will be obtained for use in checking out the experimental facilities. A series of survey calculations will be completed in support of the planned experiments.

$\underline{F Y-1978}$ ANTICIPATED FUNDING LEVEL: $\$ 190 \mathrm{k}$

Procurement of experimental criticality data will be initiated for developing the technology on nuclear criticality control in HTGR fuel cycle operations. In both fuel reprocessing and fuel fabrication plants, one of the most restrictive stages to plant throughput involves furnace type processing of normally undermoderated fuel. In fuel reprocessing plants this includes such areas as the $\sim 24-i n c h$ ID cylindrical primary burners where the outer pyrophoric carbon is removed from crushed fuel assemblies. In the fuel fabrication plant the 9inch ID cylindrical carbonization and coater furnaces normally process dry 
fuel in the form of microspheres. Either of these type systems are extremely sensitive to external reflection and water addition; consequently, a thorough knowledge of their criticality parameters is particularly required to prevent their unduly restricting plant capacity.

A series of criticality experiments with uranyl nitrate solutions, having a ${ }^{235} \mathrm{U}$ enrichment of at least $93 \mathrm{wt} \%$ and $\mathrm{H} / \mathrm{U}$ atomic ratios ranging from 12 to 300, will be initiated in bare and water-reflected cylinders. The measurements will be carried out in 12-inch ID and 24-inch ID cylinders. In the 50 to 300 $\mathrm{H} / \mathrm{U}$ atomic ratio range ( $\sim 450 \mathrm{~g}$ U/1iter to $\sim 85 \mathrm{~g}$ U/liter), criticality data will also be obtained on a 24-inch ID cylindrical vessel filled with 4 wt\% borated steel raschig rings occupying about 20 vol\% of the vesse 1 . These latter measurements wil1 provide the data needed for verifying calculations on $235 U$ solution storage vessels containing fixed neutron poisons.

$\underline{F Y-1979}$ ANTICIPATED FUNDING LEVEL: $\$ 250 \mathrm{k}$

Criticality experiments with $93 \mathrm{wt} \%{ }^{235} U$ enriched (min.) uranyl nitrate solution will be completed. Data testing and analysis of the experiments to provide validated analytical methods with ENDF/B cross sections will be initiated and completed. The results of the experiments and data correlation will be reported on in the open 1iterature. Development of standards or guides on criticality prevention and control for the HTGR fuel cycle will be initiated.

A series of criticality experiments with uranyl nitrate solutions, having a $233 \mathrm{U}$ enrichment of at least $93 \mathrm{wt} \%$ and $\mathrm{H} / \mathrm{U}$ atomic ratios ranging from 12 to 300 , will be initiated in bare and reflected cylinders. The measurements will be carried out in 12-inch ID and 24-inch ID cylinders. In the 50 to $300 \mathrm{H} / \mathrm{U}$ atomic ratio range ( $\sim 450 \mathrm{~g} \mathrm{U} / 1$ iter to $\sim 85 \mathrm{~g} \mathrm{U} / 1 \mathrm{iter}$ ), criticality data will also be obtained on a 24-in ID cylindrical vessel filled with 4 wt\% borated stee1 raschig rings occupying about 20 vol\% of the vessel. 
$\underline{F Y-1980}$

ANTICIPATED FUNDING LEVEL: $\$ 250 \mathrm{k}$

The criticality experiments with ${ }^{233} U$ solutions will be completed. Data testing and analysis of the experimental data will be performed and reported on in the open literature.

Criticality experiments will be initiated and completed to measure the effect that cadmium as a soluble neutron absorber has on the criticality of $\sim 93$ wt\% ${ }^{235} \mathrm{U}$ enriched urany 1 nitrate. Measurements will be made on solutions having $\mathrm{H} / \mathrm{U}$ atomic ratios ranging from 12 to 300 and containing up to $6 \mathrm{~g} \mathrm{Cd} / 1$ iter.

$\underline{F Y-1981}$ ANTICIPATED FUNDING LEVEL: $\$ 250 \mathrm{k}$

The experimental data obtained in previous years on ${ }^{235} U$ and ${ }^{233} U$ will be correlated and presented in the open literature. Development of standards or guides on criticality prevention and control for the HTGR fuel cycle will be continued.

Criticality experiments will be initiated and completed with 93 wt\% $233 \mathrm{~J}$ enriched uranyl nitrate solution containing up to $\sim 6 \mathrm{~g} \mathrm{Cd} / 1$ iter, and having $\mathrm{H} / \mathrm{U}$ atomic ratios ranging from 12 to 300 .

Initiate and complete experiments with $\sim 93 \mathrm{wt} \%{ }^{235} \mathrm{U}$ enriched uranyl nitrate solutions containing up to $\sim 3 \mathrm{~g} \mathrm{Gd} / \mathrm{liter}$ and having $\mathrm{H} / \mathrm{U}$ atomic ratios ranging from 12 to 300 . Based on the results of these measurements, experiments will be initiated with ${ }^{233} \mathrm{U}$ enriched uranyl nitrate solutions containing Gd. $\underline{F Y-1982}$ ANTICIPATED FUNDING LEVEL: $\$ 250 \mathrm{k}$

Complete experiments with ${ }^{233} U$ enriched uranyl nitrate containing gadolinium and report the results of the measurements in the open literature.

Calculations and experimental data on plutonium systems have indicated that mixtures of gadolinium and boron are more effective soluble neutron 
poisons over a wide range of fissile concentrations than is either one alone. (4) To provide confirmatory data in this area for highly enriched ${ }^{233_{U}}$ and ${ }^{235_{U}}$ systems, criticality experiments will be performed with 93 wt\% ${ }^{235} \mathrm{U}$ enriched uranyl nitrate solutions containing $B-G d$ mixtures and having $H / U$ atomic ratios ranging from $\sim 50$ to 300 .

The experimental data obtained on ${ }^{233} U$ and ${ }^{235} U$ enriched uranyl nitrate containing soluble neutron poisons will be correlated and published in the open literature. Standards or guides on the use of soluble poisons for criticality prevention in the HTGR fuel cycle will be developed. Recommendations on additional (if any) experiments needed for the HTGR fuel cycle will be made. $\underline{\text { FY-1983 ANTICIPATED FUNDING LEVEL: } \$ 100 \mathrm{k}}$

Correlation of data will be completed and a report issued covering criticality prevention guidelines applicable to the HTGR fuel cycle. Safe limits, serving as the basis for standards on criticality control, will be deduced including those covering the applications and use of fixed and soluble poisons. The report will be based on the ana'ysis of the critical experiments utilizing ENDF/B cross section data and modern codes; the "validated" computational methods will then be used to extend the application (and usefulness) of the report beyond the range covered in the original experiments.

\section{BEYOND FY-1983}

Experiments would be designed as necessary to handle the criticality data needs resulting from any special conditions that may be encountered in fuel cycle operations. Additional experiments would be performed, if needed, for formulating standards of excellence on criticality control. For example, the effects of Th dilution and the benefits derived therefrom may become of more interest. An experiment of interest involves determining the limiting critical 
$U$ concentration in unmoderated (dry) Th+U for which criticality is possible. The possible segregation of the fuel in dissolver operations and burner operations may require further consideration and evaluation.

The currently projected funding levels required to accomplish all phases of the research program, during the time intervals specified, are indicated by fiscal year in the table below.

\section{TABLE III}

PROJECTED FUNDING SCHEDULE

$\underline{F Y-1977} \underline{F Y-1978} \underline{F Y-1979} \underline{F Y-1980} \underline{F Y-1981} \underline{F Y-1982} \underline{F Y-1983}$

Experiments and

Data Correlation

$\begin{array}{lllllll}50 & 190 & 220 & 250 & 250 & 200 & 100\end{array}$

Experimental Vessels

(3)

Load-In Station

Transfer Lines, etc. 10

Safety and Interlock

System

10

18

Storage Tanks (2)

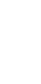

Fuel Preparation and Reprocessing 


\section{REFERENCES}

1. Oak Ridge National Laboratory, Gulf General Atomic, and Allied Chemical Corporation, "National HTGR Fuel Recycle Development Program Plan," ORNL-4702, Rev. 1, August 1973.

2. R. E. Peterson and G. A. Newby, "An Unreflected U-235 Critical Assembly," Nucl. Sci. Eng., 1, pp. 112-125 (1956).

3. E. A. Plassman and D. P. Wood, "Critical Reflector Thicknesses of Spherical U233 and Pu238 Systems," Nucl. Sci. Eng., 8, pp. 525-531 (1960).

4. R. C. Lloyd and E. D. Clayton, "Effect of Boron and Gadolinium on the Criticality of Plutonium-Uranium Systems, ANS Trans., 23, June 1976. 
APPENDIX

HTGR FUEL CYCLE

PROCESS STEPS AND MATERIAL FORM

PERTINENT TO CRITICALITY PREVENTION

PROCESS STEPS TO WHICH CALCULATIONAL OR EXPERIMENTAL WORK IS RELATED

I. FUEL FABRICATION

1. RECEIPT AND STORAGE OF EITHER URANY NITRATE SOLUTION OR U0 3 POWDER POLOWED BY DISSOLUTON POWDER PURFICATION, AND LOADING AND

IF SOL-GEL PROCESS IS USED IN MICROSPHERE PRODUCTION, THE SAME MATERIAL FORMS WILL BE ENCOUNTERE XCEPT POSSIBLE UF
MAIERIAL FORM ENCOUNTERED IN PROCESSES WHICH ARE PERTINENT TO CRITICALITY

DRY U03, UN AND UF, (IF LOAD RES INS FROM UF 6 ) SOLUTIONS, AND LOW HYDROGENOUS U0 2 AND U $\left(U-\mathrm{C}_{6} \mathrm{O}_{2} \mathrm{H}_{6}\right)$

(2)

XPERIMENTAL DATA EXISTS FOR SOLUTIONS CONTAINING LESS THAN 333 g U/ $(0 R N L-4280$, p. 55. AND ORNL 60-4-12) AND FOR A FUL DENSITY METAL SPHERE (LAMS - 3067, p. 54). DATA IS NEEDED FOR SOLUTIONS ABOVE 333 USED IN LOAING THE RESIN ALSO, DATA IS NEEDED FOR DRY AND LOW MODREATED OXIDES SOME DATA EXIST FOR ARRAYS OF UN SOLUTION UNITS IORNL-4280, 0 . 55. AND NUCLEAR APPLICATIONS, VOL 4. p. 136): HOWEVER, ADDITIONAL DATA ARE NEEDED ON SOLUTION ARRAYS AND ON ARRAYS OF DRY OXIDE UNITS REFLECTED WITH WATER AND CONCRETE. DTORAGE

BLENDING AND CO-MICROSPHERE PREPARATION ARESEN, MIXED Th-U WILL BE CATION.I

5. FUEL ELEMENT ASSEMBLY

6. FUEL ELEMENT CARBONIZATION AND ANNEALING

7. FUEL ELEMENT INSPECTION, STORAGE AND SHIPMENT

II. FUEL REPROCESSING

1. RECEIPT AND STORAGE OF FUEL

2. FUEL ELEMENT CRUSHING FOUOWED
BY WEIGHING, STORAGE, AND BY WEIGHING, STORAGE, AND PRIMARY BURNING

3. CLASSIFICATION AND STORAGE

4. CRUSHING AND SECONDARY BURNING

5. DISSOLUTION AND CENTRIFUGE

6. ACCOUNTABILITY TANK, ACID STRIP COWMN, SOWTION ADJUSTMENT AND IION COUMNS
$4-\mathrm{C}_{6} \mathrm{O}_{2} \mathrm{H}_{6}$ AT $15 \mathrm{H} / \mathrm{U}$ (MIN.) AND NONCARBONIZED RESIN PARTICLE AT ABOUT $3 \mathrm{C} / \mathrm{J}$ $\left(U C_{3} \mathrm{O}_{0.5}\right)$ CARBON COATED UC ${ }_{3} 0_{0}$ PARTICLES $\left.{ }^{2} \mathrm{C}_{3} \mathrm{H}_{6} \mathrm{OR} \mathrm{CH}_{4}\right)$

CARBON COATED U AND Th PARTICLES AT A Th/U RATIO BETWEEN ZERO AND 20 NORMALYY 4.231, AND CIN OF FRI I IS TOS DIAMETER AND 2-3 INCHES IN IENGTH

HEXAGONAL GRAPHITE BLOCKS, 31-IN, CONTAINING SOME 2000 FUEL RODS ATER IMMERSION OF FUEL ELEMENTS CONSIDERED POSSIBILITY

DRY FUEL ELEMENT

WATER REFLECTED DRY FUEL ELEMENTS

CARBON COATED U AND CARBON COATED Th-U AND GRAPHITE AGGREGATES HAVING CIU RATIOS 3 TO 5000. IIF STRATIFICATION OCCURS TO THE EXTEN PARTICLS SEPARATE AND GRAPHITE OF 3 IS THEORETICALYY POSSIBLE ALTHOUGH A RATIO OF ABOUT GO CIU IS CONSIDERED MOST CREDI BLE,

CARBON-COATED U AND CARBON-COATED Th-U PARTICLES IINITIALLY, BOTH U AN EVENTUALY ONLY THE FISSILE U PARTICLSS WIL BE SIC COATED I AT 40 Th/U.

CARBON COATED U PARTICLES OR CARBON COATED Th-U PARTICLS IBOH MAYHAVE SIC COATINGS ALSO, AS DISCUSSED IN DS ALSO AS DISCUSSED IN OXIDES IN THIS STEP.

BURNER ASH FROM SECONDARY BURNER CONTAINING ThO 2 AND UO2. SLURRY O HULLS SIC HULIS AND C IN HNO HF. NEUTRON POISONS MAY BE PRESENT.

THORIUM-URANIUM NITRATE SOLUTIONS NO EXPER
SOLUTIONS

NO DATA EXIST WHICH ARE APPLICABLE TO THESE PROCESS STACES. DATA ARE NEEDED ON LOW MODERATED OXIDE AND CARBIDE SYSTEMS

NO DATA EXIST WHICH ARE APPLICABLE TO THESE PROCESS CONDITIONS. DATA ARE CARBON SYSTEMS.

DATA EXIST FROM REACTIVITY WORTH MEASUREMENTS OF RODS IN GRAPHITE. PERFORMED IN SUPPORT OF HIGR DESIGN IN THESE EXPERIMENTS CONTAINED NO THORIUM AND NO CIU RATIOS BELOW 432 ITHE LATER IS PROBABLY NOT IMPORTANT, SINCE GOOD CALCULATIONAL RESULTS WERE OBTAINED FOR CIU RATIOS BETWEEN 432 AND 2500). MEASURED $k_{\infty}$ AND Th/U RATIOS (ABOVE 10) FOR Th-U GRAPHITE MIXTUIRES (BNWL-156] BNWL-1601!

DATA ARE AVAILABLE AS INDICATED ABOVE IN 1.4

NO DATA

DATA EXIST FOR DRY FUEL ELEMENIS, AS COVERED IN 4 ABOVE; HOWEVER, NO DATA WILL BE ENCOUNTERED DURING FUEL ELEMENT STORAGE

DATA EXIST FOR DRY FUEL ELEMENTS ISEE 1.4); HOWEVER NO INFORMATION ON ARRAYS,

NO DATA EXIST THAT ARE APPLICABLE TO THIS TYPE SYSTEM. SOME REACTIVITY WORTH MEASUREMENTS IN SUPPORT OF THE HTGR DESIGN EXIST (1.4); HOWEVER, THIS DATA DOES AND TER THE RATO RANGE BELOW 400 IS MUCH SOFTER THAN THAT ENCOUNTERED IN THESE PROCESS STEPS ALSO THE EFFECTS THAT Th HAS ON REACTIVITY CANNOT BE VERIFIED FROM THESE HTGR EXPERIMENTS.

NTAL DATA EXIST FOR Th-U VALUES EXIST AT HIGH CIU IABOVE 2500
NO EXPERIMENTAL DATA EXIST FOR Th-U OLUTIONS

EXPERIMENTAL DATA EXIST FOR SOLUTIONS AND ORNL 60-4-12). CONTAINING LESS THAN 333 g U/l (ORNL-4280

\section{URANYL NITRATE UP TO $350 \mathrm{~g} \mathrm{U/L}$}

URANYL NITRATE UP TO $350 \mathrm{~g}$ U/L AND ORY UO 


\section{DISTRIBUTION}

No. of

Copies

OFFSITE

1

ERDA Chicago Patent Group

U.S. Energy Research and Development Administration

Chicago Operations Office

9800 South Cass Avenue

Argonne, Illinois 60439

A. A. Churm

Division of Nuclear Fuel Cycle and Production

Energy Research and Development Administration

Washington, D. C. 20545

5

Deputy Director

Mr. W. S. Scheib, HTGR Recycle Branch

27

ERDA Technical Information Center

Office of Program Management - Research and Space Programs Energy Research and Development Administration

P. 0. Box 81325

San Diego, California 92138

1

Coordinator

Office of Program Management - Research and Space Programs

Energy Research and Development Administration

1333 Broadway

Oakland, Cal ifornia 94612

1

Manager

Idaho Operations Office

Energy Research and Development Administration

P. 0. Box 2108

Idaho Fal1s, Idaho 83401

$1 \quad$ Manager

Mr. Barry Smith

Mr. C. W. Bills, Assistant Manager for Production \& Technical Support 
Allied Chemical Corporation

Idaho Chemical Programs-Operations Office 550 2nd Street

Idaho Falls, Idaho 83401

Mr. B. R. Wheeler, Director HTGR Program Office

Mr. W. G. Morrison

Mr. A. P. Roeh

Dr, R. E. Wilson

General Atomic Company

Post Office Box 81608

San Diego, California 92138

Mr. W. V. Goeddel

Mr. Colin A. Heath

Oak Ridge Operations Office

Energy Research and Development Administration

P. 0. Box E

Oak Ridge, Tennessee 37830

Mr. J. A. Lenhard, Director Research \& Technical Support Division

Mr. H. O. Baker, Director, Engineering Division

Mr. R. L. Egli, Director Reactor Division

Mr. J. T. Milloway, Deputy Assistant Manager Construction \& Engineering Mr. F. E. Dearing $\frac{\text { Oak Ridge ilational Laboratory }}{\text { P. O. Box X }}$

Oak Ridge, Tennessee 37830

$P$. Angelini

R. J. Beaver

R. A. Bradley

A. J. Caputo

J. A. Carpenter

J. H. Coobs

D. A. Costanzo

F. C. Davis

J. P. Drago

R. G. Donnelly

W. P. Eatherly

J. R. Engel

D. E. Ferguson

P. A. Haas

C. C. Haws

W. R. Hamel

R. M. Hil1

F. J. Homan

J. D. Jenkins

D. R. Johnson 
Oak Ridge National Laboratory (continued)

P. R. Kasten

R. K. Kibbe

R. W. Knoll

W. J. Lackey

E. L. Long, Jr.

A. L. Lotts

J. E. Mack

A. P. Mal inauskas

S. R. Mcileany

K. J. Notz

A. R. 01 sen

W. H. Pechin

D. P. Reid

J. E. Rushton

T. F. Scanlan

C. D. Scott

D. P. Stinton

R. R. Suchomel

V. J. Tennery

S. M. Tiegs

T. N. Tiegs

J. T. Thomas

D. B. Trauger

J. E. Van Cleve

J. R. Weir

G. E. Whitesides

R. G. Wymer

G. W. Weber

R. M. Young

ERDA Richland Operations Office

F. R. Standerfer

B. J. Melton

H. A. House

P. A. Craig

Battelle-Northwest

S. R. Bierman

E. D. Clayton

N. E. Carter

C. L. Brown

Technical Information Files

Technical Publications 